\title{
Laxmi Sharma: A Woman's Adventure in Entrepreneurial World
}

\section{Sushil Kumar Pant}

THE STORY OF LAXMI SHARMA begins with a humble middle class background. She was born in a farmer's family which is common for most of Nepalese. So her early childhood was no different from any other child in the country. However, a turning point came not much later. When she was only five, she was sent to one of the palaces in the country as a maid servant. The Princess was Bunu Maharani, a sister of the then king Tribhuvan.

This was the beginning of the learning of ups and downs of life. She was assigned a job of cleaning the temple inside the palace as well as preparing for daily Puja. In the process she learnt how to speak, how to behave with people and today she thinks that was the time when she was spoilt. When asked why she thought so she told that being a small and beautiful child other maid and people in the palace used to pamper her. Although she was a maid she had a special status in the palace. However, she thinks that it was an educational institution for her to learn the life skills.

Another important turning point came quite early. When she was only nine, the Princess died. Hence she had to leave the palace and came back to her parental home. Now, the life took a harsh path for a child of that age. A girl who spent quite some time in a palace had to face the reality of the life. The house was not even a decent house rather it was a small hut made of thatch and mud. Parents sent her to a school which she left only after attending for three days. That was the end of her formal education.

\section{The struggle}

As per the practice of the time she was married when she was only thirteen years old. She had her first child very next year which unfortunately was miscarried. She went through the same experience once again. She had her first live child when she was twenty. Then another shock came in her life. As she was in hospital after the child birth her husband's girlfriend turned into the hospital and started to abuse her. She felt very bad for that. But never gave up. She began to live independently and started a new life with the child. However, later she had two more children, all girls.

When the first child was only three month old she started to work in an expatriate's (A Russian diplomat) home. She continued to live in her parental home with children. Working in foreigners' homes continued where she learnt to understand and speak English language. She also learnt cooking different types of food and other aspects of behavior.

At the age of 25 she had to leave her husband for ever and began a completely independent life which was a difficult phase of life because in Nepal a woman without a male member to look after is taken by a surprise. So that was really a downside of the life. However the fighter inside Laxmi did not surrender to the hardships. She committed to herself that despite the problems she would make her children a Thulo Manchhe (someone special with high socio-economic status). For that she worked up to 19 hours a day.

In 1979 she left the job of serving in the expatriates' homes because she felt that she had been exploited and was extremely unhappy with what she was doing. However, the 
need for survival was a big issue. She started to plan for the future when one skill came as a rescue. She used to prepare some post cards in her leisure time and sold it to those foreigners with whom she worked. This helped her in small way during those days. Howevers after leaving the safety of working for others and getting paid at the end of a month she had no option but worked little hard to make the skill a serious means for living.

She also began to wash wool used to make carpets for living. At this point in time she met with a cousin of an American to whom she worked. The girl came forward to help her. She took her to India in August 1979 in a visit where she explored some entrepreneurial venture. After some time she was again sent to India (Benaras) for a short term training to run machines. After having some ideas in machine she bought a Tempo (a three wheeler vehicle) to earn for the living after borrowing Rs 10,000 from her aunt. The venture was successful and she had four Tempos in a short time span of one and half years. However later she realized that the drivers were cheating her and left the business. In the mean time, she went to Benaras, India and learnt to maintain the Tempo and started a workshop in Kathmandu to maintain the vehicle. It was a first time a woman had started such kind of maintenance shop in the capital. However the gender came as a hindrance. People did not believe her. The drivers of the Tempo, who were all men, had doubt in her ability to provide high quality maintenance for their vehicles. She was burdened by Rs.70,000 as a loan because of the business. Therefore she had no option but to leave the business.

\section{The Turning Point}

In 2043 B.S. she started Laxmi craft which produced handicraft products targeted to tourists. The choice of the business was because she knew through working with foreigners that they liked Nepalese handicraft and realized that there was good market for it. After two years she began to manufacture buttons with initial investment of Rs 5,000 which was a novel business for Nepal. The product was unique in a sense that it is based on handicraft principles. They are made from bones of domestic animals, wood, bamboo, seeds of some of the fruits among others. Besides buttons, she continued to manufacture handicraft products made of Nepali handmade paper, pashmina, cotton, wool etc.

Though the initial experience with the business was good she had problem of credit sales. It was difficult to recover the money invested due to the non payment of goods sold on credit. Banks were also not helpful because she did not have property to pledge for collateral. So she was denied with the loan. Even the government was of no help. She received no special facilities from the government. It was entirely on her own she did what she was doing.

After the early success she had opportunity to go to USA and Europe to search the market. That taught her to design and supply the products as per the demand of the consumers which is one of the secret of success.

Laxmi brought some Indian workers with relevant skills to begin with. Then she started to train Nepalese workers. The selection of apprentice was based on taking anybody who claims s/he suffered from economic difficulty. She would not only train them but also pay Rs.500 as stipend. She continued to do so even today and pays Rs. 1,500 as stipend. The entire venture therefore is self created and works like a big family.

Current annual turnover of the business is Rs. 20 million of which 99 percent is ex- 
ported to US, Europe and other countries all over the world. The enterprise employees 150 people of which 35 percent is female.

\section{Marketing}

The marketing of the product is quite simple. She directly contacts with the customers without employing any middleman. In fact, customers from all over the world come to Nepal and find her products and put order for the same. Once the importer takes the product to his/her country becomes a permanent customer. More customers come through referral of already satisfied customers. The enterprise and Laxmi herself are members of several international organizations including Global Compact, Federation of Women Enterprises in the US among others. They help bring new customers.

\section{The Philosophy}

When asked about the philosophy of life which drives her she answers humbly about three things in life. They are: honesty, reliability and confidence. She also told that after all the early age sufferings she wanted to show the world that a single woman can do wonders. She was also driven by the orientation of doing something different. The choice of business was also influenced by marrying to a traditional Brahmin family. Because of this she had to choose a business which looked "decent" in the eyes of traditional Nepali society. Otherwise she could have faced many socio-cultural problems.

She also believes that the four years she had spent in the Palace where she got some knowledge of religion later helped her to believe in herself and not to surrender against any difficulties.

She has a message to the new generation. She says "Always believe in yourself, be committed to what you are doing and take advantages of the support you get from the government and other agencies without any hesitation." However she is also worried about the impatience demonstrated by today's youth. She asks today's youth to work hard in the country itself rather than going in a foreign country and selling labor for anything.

\section{Future Plans}

Her future plan includes an ambition to open her own outlet in USA and Australia, of which Australia is the priority as one of her daughters is living there. The next dream is to open an institute to train young people in handicraft designing because she sees the future of Nepalese entrepreneurs in it. 